\title{
Evolution of stomach cancer mortality in Brazil and its regions, by sex, 2011-2015
}

\author{
Evolução da mortalidade do câncer de estômago no Brasil e suas regiões, por sexo, 2011-2015 \\ Evolución de la mortalidad por cáncer de estómago en Brasil y sus regiones, según sexo, 2011-2015
}

Received: 02/09/2022 | Reviewed: 02/16/2022 | Accept: 02/18/2022 | Published: 02/26/2022

\author{
Willams Alves da Silva \\ ORCID: https://orcid.org/0000-0002-4603-3049 \\ Universidade Federal do Ceará, Brasil \\ E-mail: willams_alves@hotmail.com \\ Isabel Michely da Silva Galvão de Melo \\ ORCID: https://orcid.org/0000-0003-0896-0447 \\ Universidade Federal do Ceará, Brasil \\ E-mail: michely.isabel@gmail.com \\ Vanessa Gomes Amaral Almeida \\ ORCID: https://orcid.org/0000-0001-5641-3654 \\ Centro Universitário CESMAC, Brasil \\ E-mail: vanessaamara103@hotmail.com \\ Janayze Suéllen de Lima Mendes Silva \\ ORCID: https://orcid.org/0000-0001-7496-8207 \\ Universidade Federal Rural de Pernambuco, Brasil \\ E-mail: janayzesuellen@ hotmail.com \\ Mary Anne Medeiros Bandeira \\ ORCID: https://orcid.org/ 0000-0003-0550-8308 \\ Universidade Federal do Ceará, Brasil \\ E-mail: mambandeira@yahoo.com.br \\ Marlon Claudener dos Santos Dantas \\ ORCID: https://orcid.org/ 0000-0003-3827-4448 \\ Universidade Federal de Sergipe, Brasil \\ E-mail: marlonclaudener@hotmail.com \\ Isabela Malta Maranhão \\ ORCID: https://orcid.org/0000-0002-6867-8892 \\ Centro Universitário CESMAC, Brasil \\ E-mail: isabelammaranhao@gmail.com \\ Sônia Pereira Leite \\ ORCID: https://orcid.org/0000-0002-0634-9735 \\ Universidade Federal de Pernambuco, Brasil \\ E-mail: spleite6@hotmail.com \\ Kristiana Cerqueira Mousinho \\ ORCID: https://orcid.org/0000-0003-0985-3336 \\ Centro Universitário CESMAC, Brasil \\ Universidade Estadual de Ciências da Saúde de Alagoas, Brasil \\ E-mail: kristianamousinho@gmail.com
}

\begin{abstract}
To describe the distribution pattern of the stomach cancer mortality rate in Brazil and its regions, according to sex, between the year 2011 and 2015. Mortality values were described by the DATASUS atlas mortality and stratified by sex in the year 2011 and 2015 and analyzed by the Two-Way Anova test. It was observed that there was a higher mortality incidence in the Southeast and lower in the Midwest for both sexes. The Northeastern region presented a high number of cases standing out in relation to the North, Center-west and South regions $(\mathrm{P}<0.05)$. Regarding the incidence of male mortality, the North and Northeast regions showed continuous growth over the 5 years studied in this study. On the other hand, the Central-West, South and Southeast regions showed small variations, with 2013 being the most affected in the Midwest and Southeast and 2012 in the South. However, these variations were not significant in terms of statistical test. It is important to know these mortality rates in the regions to identify and define priority regions for early interventions that increase survival and reduce mortality in these populations.
\end{abstract}

Keywords: Neoplasm of stomach; Mortality, Regions of Brazil; DATASUS.

\section{Resumo}

Descrever o padrão de distribuição da taxa de mortalidade por câncer de estômago no Brasil e suas regiões, segundo sexo, entre o ano de 2011 e 2015. Foram descritos os valores de mortalidade através do levantamento no atlas de mortalidade do DATASUS e estratificada por sexo no ano de 2011 e 2015 e analisadas através do teste Two-Way Anova. Observou-se que houve uma incidência de mortalidade maior no Sudeste e menor no Centro-oeste para ambos 
os sexos. A região Nordeste apresentou um elevado número de casos se sobressaindo em relação as regiões Norte, Centro-oeste e Sul $(\mathrm{P}<0,05)$. Em relação a incidência de mortalidade no sexo masculino, a região Norte e Nordeste apresentou crescimento continuo ao longo dos 5 anos estudados neste trabalho. Já as regiões Centro-oeste, Sul e Sudeste apresentaram pequenas variações, sendo o ano de 2013 o que houve mais incidência no Centro-oeste e no Sudeste e o ano de 2012 para a região Sul. Contudo estas variações não foram significativas a nível de teste estatístico. Importante conhecer essas taxas de mortalidade nas regiões para identificar e definir regiões prioritárias para intervenções precoces que aumentem a sobrevida e reduzam a mortalidade destas populações.

Palavras-chave: Neoplasia de estômago; Mortalidade; Regiões do Brasil; DATASUS.

\begin{abstract}
Resumen
Describir el patrón de distribución de la tasa de mortalidad por cáncer de estómago en Brasil y sus regiones, según sexo, entre 2011 y 2015. Los valores de mortalidad fueron descritos a través de una encuesta en el atlas de mortalidad DATASUS y estratificados por sexo en 2011 y 2015 y analizada mediante la prueba Anova de dos vías. Se observó que hubo mayor incidencia de mortalidad en el Sudeste y menor en el Medio Oeste para ambos sexos. La región Nordeste presentó un elevado número de casos, destacándose en relación a las regiones Norte, Centro Oeste y Sur $(\mathrm{P}<0,05)$. En cuanto a la incidencia de mortalidad en el sexo masculino, las regiones Norte y Nordeste mostraron un crecimiento continuo a lo largo de los 5 años estudiados en este trabajo. Las regiones Centro Oeste, Sur y Sudeste presentaron pequeñas variaciones, siendo el 2013 el año de mayor incidencia en el Centro Oeste y Sudeste y el 2012 para la región Sur, sin embargo, estas variaciones no fueron significativas a nivel de prueba estadística. Es importante conocer estas tasas de mortalidad en las regiones para identificar y definir regiones prioritarias para intervenciones tempranas que aumenten la supervivencia y reduzcan la mortalidad en estas poblaciones.
\end{abstract}

Palabras clave: Neoplasia de estómago; Mortalidad; Regiones de Brasil; DATASUS.

\title{
1. Introduction
}

Stomach cancer is a serious public health problem that despite having its incidence and mortality rates reduced in the last 30 years deserves relevant attention (Ang \& Fock, 2014). It is the second most common in the world, second only to lung câncer (Garcia, 2013). In Brazil, the occurrence varies among the regions due to demographic and socioeconomic heterogeneity. Although there has been a decrease in cases in the Midwest, South and Southeast, it has been increasing in the North and Northeast (Souza et al., 2016). Its prevalence is higher among men than in women (Braga-Neto et al., 2018).

In 1980, stomach cancer was the most common malignancy in the world, however, with a decline of $2.2 \%$ per year observed. In their incidence rates and with the increase of the frequency of lung cancer, that situation has changed. The decrease in rates incidence and mortality, which has been observed in several countries, is higher in USA (Abreu, 1997).

Also called gastric cancer, stomach tumors present predominantly in the form of three histological types: adenocarcinoma (responsible for $95 \%$ of tumors), lymphoma, diagnosed in about $3 \%$ of cases, and leiomyosarcoma, initiated in tissues that give origin of muscles and bones (Brasil, 2020; Martinez, 2020).

According to the National Cancer Institute (INCA), malignant tumors are among the tumors that kill the most in Brazil, ranking third among men and fifth among women. The disease is more common in men, around age 70 . About $65 \%$ of people diagnosed with stomach cancer are over 50 years old (Brasil, 2020).

Risk factors include a diet high in salt, poorly preserved foods (Braga-Neto et al., 2018), soft drinks, animal products and fats (Villaverde et al., 2017). Reduced consumption of fruits and vegetables indicates a deficiency of important nutrients, since vegetables present compounds that perform various biological activities in the organism as protection against cardiovascular diseases and cancerous tumors (Hawkesworth et al., 2017).

A low socioeconomic level may also indicate diets low in vitamins and minerals and poor access to health care (Guedes et al., 2014). Smoking, overweight and sedentary lifestyle also contribute to the development of various types of câncer (Grundy et al., 2017).

Some diseases such as chronic gastritis and gastric ulcers caused by H. pylori and pernicious anemia (Villaverde et al., 2017), familial adenomatous polyposis (Nakamura et al., 2017) and gastroesophageal reflux disease (Csendes \& Figueroa, 2017; Silva, 2018) favor the exposure of the gastric mucosa and predispose patients to develop stomach cancer. 
The disease manifests itself silently, as it is asymptomatic in 80\% of cases (Garcia, 2013). In the initial phase, the symptoms have no specificity and this causes a delay in diagnosis and the discovery of the tumor at a later stage (Braga-Neto et al., 2018). Patients with gastric cancer may present with nausea, dysphagia and early satiety (Villaverde et al., 2017).

The prognosis of stomach cancer is one of the most difficult, since most patients are diagnosed late (Vilela et al., 2018) Early detection of the tumor may result in a more effective treatment, but in rural areas, where public health is precarious and few endoscopic equipment is available, it is difficult to identify the cancer at an early stage (Lopez-Ramírez et al., 2017; Renal \& Retroperitoneais, 2018).

Prevention of stomach cancer involves reducing exposure to risk factors such as smoking, foods rich in preservatives and salt, conducting periodic examinations for early detection of the disease and more effective treatment (Csendes \& Figueroa, 2017; Toneto \& Viola, 2018).

The only Brazilian stomach cancer survival study was carried out in Campinas, sp. Survival was observed relative rate of $33 \%$ and $9 \%$ at the end of the first and fifth year after diagnosis, respectively. No difference was found in stomach cancer survival. Between the sexes and the prognosis was better for younger individuals (Bustamante- Teixeira et al., 2006).

Early diagnosis is considered the factor with the greatest positive impact on the prognosis of patients with stomach cancer, which reveals the importance of knowing and studying the risk factors associated with carcinogenesis to guide interventions aimed at diagnosis in high-risk groups (Besagio et al., 2021; Brum et al., 2021). The objective of this study was to describe the distribution pattern of the stomach cancer mortality rate in Brazil and its regions, according to sex, between the year 2011 and 2015 .

\section{Methodology}

To be treated this is a descriptive and quantitative study, this work was performed using secondary data, which were collected from the Department of Informatics of the Unified Health System (DATASUS) (Silva Santos et al., 2019).

In order to collect data, a search was performed on the DATASUS website in: access to health information / information (TABNET) / vital statistics / cancer (INCA site) / Atlas of proportional mortality not adjusted for cancer, Brazil or Region, men, women or men and women; group, Cid and by selected year or period.

The literature review to compose the descriptive part of this work was done from the online database Scielo and Pubmed. The time interval chosen was the last 5 years and the keywords used were stomach and stomach cancer cancer.

The Excel program for Windows was used for tabulation of the data and the statistical analyzes were evaluated through the statistical program GraphpadPrism version 7.0a. Continuous variables were analyzed for their normality through the Two-Way Anova test, with those with normal distribution being presented in values of means and standard deviation. At the end of the analysis, only variables with a value of $\mathrm{p}<0.05$ were considered to be associated with the outcome in a statistically significant way.

\section{Results and Discussion}

During the years 2011 to 2015 the mortality of stomach cancer in the regions of Brazil, as seen in Graph 1, was higher in the Southeast region for both females and males, and there was a lower incidence in the Central-West region for both sexes. The Northeastern region presented a high number of cases standing out in relation to the North, Center-west and South regions. 
Graph 1. Mortality of stomach cancer in the regions of Brazil between the years 2011 to 2015 (A). The incidence of stomach cancer in men (B) and in women (C) between the years 2011 to 2015.

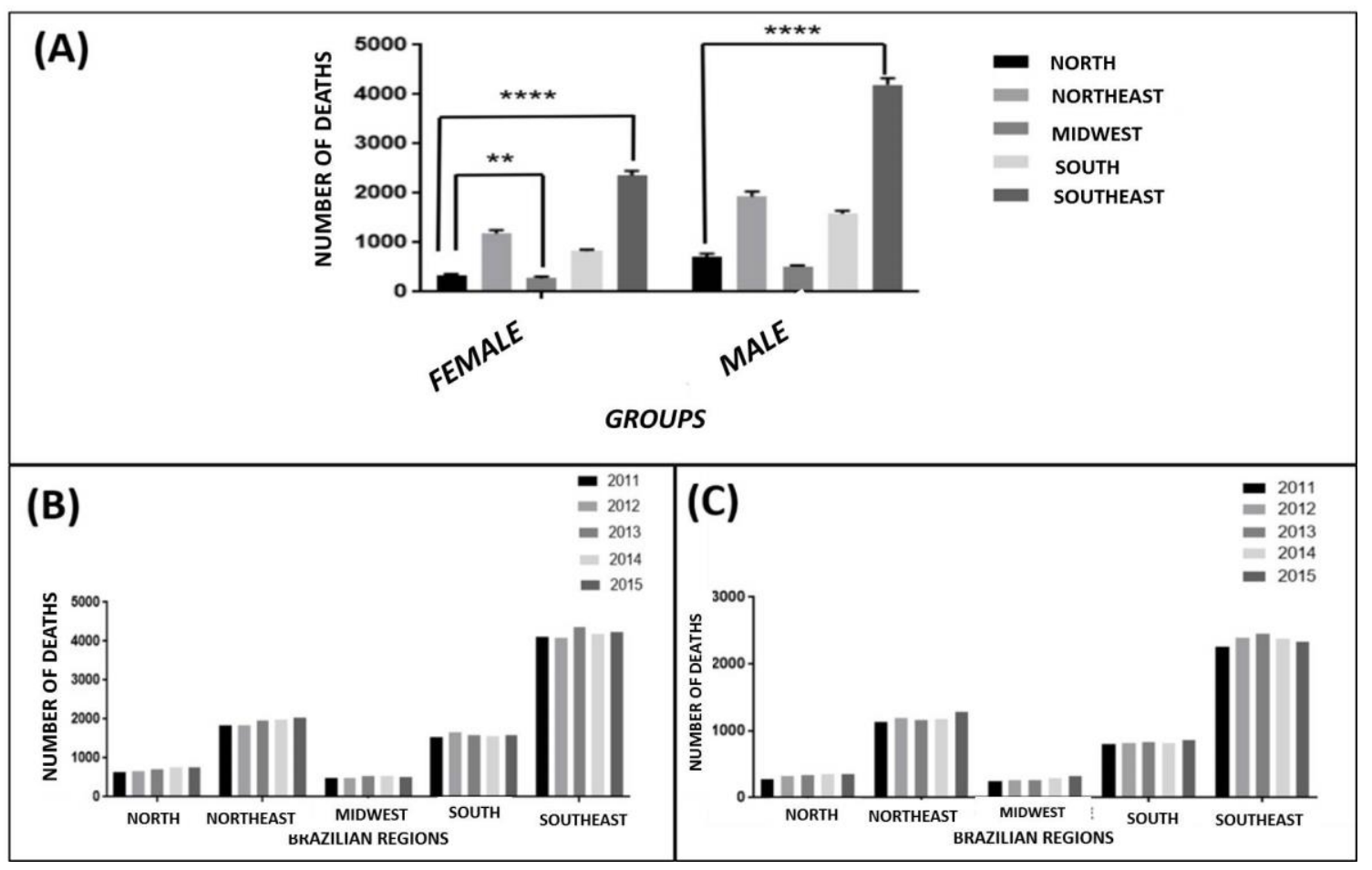

Source: Authors (2022).

Regarding the incidence of male mortality, the North and Northeast regions showed continuous growth over the 5 years studied in this study. On the other hand, the Central-West, South and Southeast regions showed small variations, with 2013 being the most affected in the Midwest and Southeast and 2012 in the South. However, these variations were not significant in terms of statistical test.

Regarding the incidence of female mortality, the regions that presented continuous growth were North and Centerwest, although the latter showed that there was a lower incidence in relation to all the other regions during the 5 years studied in this study. The Northeast, South and Southeast regions showed small variations, with the year 2015 having the highest incidence in the Northeast and South regions and 2013 in the Southeast region, which even decreased until 2015, the last year studied in this study.

In relation to growth in the number of deaths (figure 1), the north region showed the highest growth among all the others, with the percentage of $20 \%$ from 2011 to 2015. 
Figure 1. Incidence of the increase in \% of stomach cancer deaths in the regions of Brazil between the years 2011 to 2015.

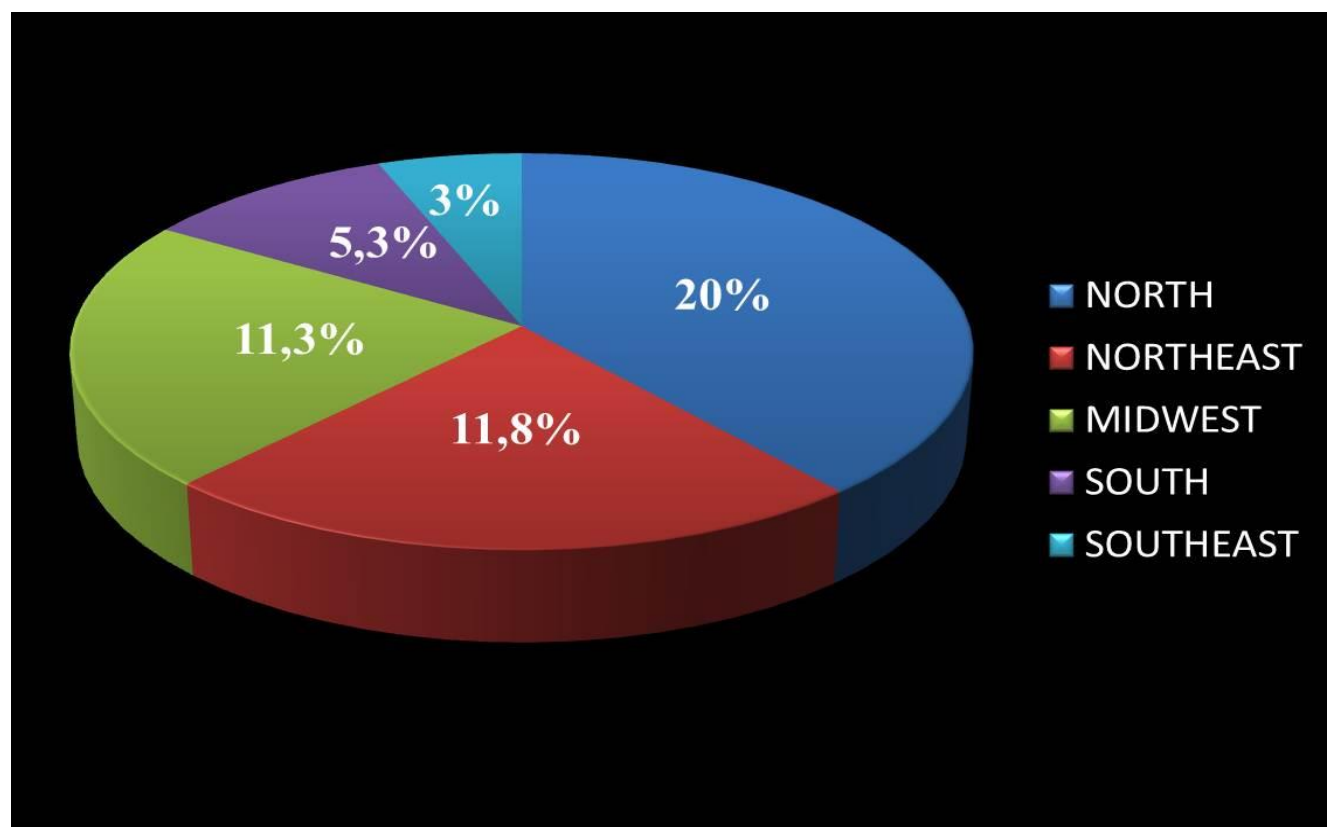

Source: Authors (2022).

The Southeast region practically maintained the statistical average in relation to the number of deaths cases, even though the region stands out in relation to the number of cases, indicating a rate of 3\% increase from 2011 to 2015 . The Northeast and Central-West regions showed an increase at almost the same rate, with 11.8\% for region and $11.3 \%$ for the Central-West region. The South region had an increase of 5.3\% between 2011 and 2015.

A factor that may explain the decrease in the incidence of female mortality in the northeastern region from 2013 may be related to the fall in the number of smokers in Brazil. According to data from the last VIGITEL survey in 2016 (Vigitel Brasil, 2016), it showed that in 2011, 10.7\% of the Brazilian population were smokers and in 2015 decreased to $8.3 \%$.

This high death rate in the northern region, even though it has presented the fewest cases, can be caused by antibiotic therapy, such as amoxilin, which is widely used in the fight against Helicobacter pylori, and will lead to gastrointestinal dysbiosis. It can cause a higher incidence of stomach cancer and consequently a high mortality rate due to this disease (Choi et al., 2018).

In Brazil, from 1980 to 2006, there was a significant decline in the trend of mortality from stomach cancer among men $(-0.28 ; \mathrm{p}<0.01)$ and women $(-0.12 ; \mathrm{p}<0.01)$. Despite this, the rates were considered high in relation to other countries. Other studies, especially focused on the northern region of Brazil, also point to a significant decline in mortality from this neoplasm (Brasil, 1996).

The southeastern region that has the highest mortality rate after the year 2013 was a reduction that was not significant. With the new RDC 44/2010 (Brasil, 2010) published by ANVISA that banned the purchase of antibiotics without prescription, it suggests that there was a provoked a decrease or stabilization in the incidence of deaths. For, without access to uncontrolled medication, mainly antibiotics, the population may have had a lower rate of intestinal dysbiosis consequently decreasing the mortality rate from stomach cancer.

Viacava and Bellido (2016) studied the coverage of health plans in the Brazilian regions of 1998, 2003, 2008 and 2013. It was evidenced that the northern region has a lower coverage index when compared to the other regions, which differs from the southeastern region that has the higher coverage ratio. This article corroborates with our study where it was 
demonstrated in the north region a high mortality rate from stomach cancer in the year 2011 to 2015 , suggesting a precariousness in the service and health access of the population in this region.

\section{Conclusion}

Since the mortality of stomach cancer is increasing in some regions, especially the one that has a scarce service and health access, this makes it difficult to diagnose and treat early, raising this death rate. Therefore, it is necessary to create measures to promote the population health.

From the information obtained, hypotheses can be raised about the behavior of mortality rates from stomach cancer, which can be tested in future studies. In addition, it is believed that current strategies to combat stomach cancer should be reinforced to maintain the downward trend observed in this work.

Despite advances in public public policies, there is a need to strengthen health surveillance in order to subsidize preventive policies for the formulation of screening and early diagnosis programs, considering the benefit of the population and the reduction of the mortality. Therefore, it is worth emphasizing the need to carry out more studies in this Brazilian population.

\section{References}

Abreu, E. D. (1997). A prevenção primária e a detecção do câncer de estômago. Cadernos de Saúde Pública, 13, S105-S108.

Ang, T. L., \& Fock, K. M. (2014). Clinical epidemiology of gastric cancer. Singapore medical journal, $55(12), 621$.

Besagio, B. P., de Andrade, E. C., Cardoso, G. G., Couto, L. C., Santini, J. X., Nunes, P. L. P., \& de Carvalho, F. B. (2021). Câncer gástrico: Revisão de literatura Gastric Cancer: A Literature Review. Brazilian Journal of Health Review, 4(4), 16439-16450.

Braga-Neto, M. B., Carneiro, J. G., de Castro Barbosa, A. M., Silva, I. S., Maia, D. C., Maciel, F. S., \& Braga, L. L. (2018). Clinical characteristics of distal gastric cancer in young adults from Northeastern Brazil. BMC cancer, 18(1), 1-7.

Brasil. (2010). ANVISA. RDC-44/2010. https://:www.anvisa.gov.br/

Brasil. (2020). Ministério da Saúde. Instituto Nacional de Câncer José Alencar Gomes da Silva. Estimativa 2020: incidência de câncer no Brasil. INCA. https://www.inca.gov.br/

Brasil. (1996). Ministério da Saúde. Instituto Nacional de Câncer José Alencar Gomes da Silva. Estimativa 2020: incidência de câncer no Brasil. INCA. https://www.inca.gov.br/

Bustamante-Teixeira, M. T., Faerstein, E., Mariotto, Â., Britto, A. V. D., Moreira Filho, D. D. C., \& Latorre, M. D. R. D. D. O. (2006). Sobrevida em pacientes com câncer gástrico em Campinas, São Paulo, Brasil. Cadernos de Saúde Pública, 22, 1611-1618.

Brum, L. S. A., Dantas, C. M. M., da Silva Machado, M., de Almeida, M. S., Linhares, I. C., \& Ferraz, A. R. (2021). Estudo sobre câncer gástrico, seus fatores de risco e prognósticos: uma revisão integrativa. Revista Eletrônica Acervo Científico, 38, e9214-e9214.

Csendes, A \& Figueroa, M. (2017). Situation of gastric cancer in the world and in Chile.Rev Chil Cir.69:502-7.

Choi, I. J., Kook, M. C., Kim, Y. I., Cho, S. J., Lee, J. Y., Kim, C. G., ... \& Nam, B. H. (2018). Helicobacter pylori therapy for the prevention of metachronous gastric cancer. New England Journal of medicine, 378(12), 1085-1095.

Garcia, C.C. (2013). Update of the diagnosis and treatment of gastric cancer. Rev Med Clin Condes. 24:627-36.

Guedes, M. T., de Jesus, J. P., de Souza Filho, O., Fontenele, R. M., \& Sousa, A. I. (2014). Clinical and epidemiological profile of cases of deaths from stomach cancer in the National Cancer Institute, Brazil. ecancermedicalscience, 8.

Grundy, A., Poirier, A. E., Khandwala, F., Grevers, X., Friedenreich, C. M., \& Brenner, D. R. (2017). Cancer incidence attributable to lifestyle and environmental factors in Alberta in 2012: summary of results. Canadian Medical Association Open Access Journal, 5(3), E540-E545.

Hawkesworth, S., Silverwood, R. J., Armstrong, B., Pliakas, T., Nanchahal, K., Sartini, C., \& Lock, K. (2017). Investigating the importance of the local food environment for fruit and vegetable intake in older men and women in 20 UK towns: a cross-sectional analysis of two national cohorts using novel methods. International Journal of Behavioral Nutrition and Physical Activity, 14(1), 1-14.

Lopez-Ramirez, M. A., Lever-Rosas, C. D., Motta-Ramirez, G. A., Rebollo-Hurtado, V., Guzman-Barcenas, J., Fonseca-Morales, J. V., \& Carreno-Lomeli, M. A. (2017). Correlation between preoperative tomographic staging and definitive histopathologic results in gastric cancer at the Hospital Central Militar. Revista de Gastroenterología de México (English Edition), 82(3), 210-216. 
Research, Society and Development, v. 11, n. 3, e37011326796, 2022

(CC BY 4.0) | ISSN 2525-3409 | DOI: http://dx.doi.org/10.33448/rsd-v11i3.26796

Martinez, E. J. J. (2020). Perfil epidemiológico dos óbitos por câncer de estômago no estado do tocantins no período de 2010 a 2018; epidemiological profile of deaths from stomach cancer in the state of tocantins from 2010 to 2018. Revista de Patologia do Tocantins, 7(3), 84-87.

Nakamura, K., Nonaka, S., Nakajima, T., Yachida, T., Abe, S., Sakamoto, T., \& Hirota, S. (2017). Clinical outcomes of gastric polyps and neoplasms in patients with familial adenomatous polyposis. Endoscopy International Open, 5(03), E137-E145.

Renal, V., \& Retroperitoneais, T. (2018). Estimativa 2018: incidência de câncer no Brasil. Revista Brasileira de Cancerologia, 64(1), 119-120.

Silva, A. B. (2018). Análise da taxa de mortalidade por câncer de estômago entre 2000 e 2015 na Paraíba, Brasil. Arquivos de Ciências da Saúde, 25(3), 18-21.

Silva Santos, D. A., Marques, A. L. A., de Olinda, R. A., \& Goulart, L. S. (2019). Perfil epidemiológico da tuberculose em um município do sul do estado de Mato Grosso. Revista Interdisciplinar, 12(2), 25-33.

Souza Giusti, A. C. B., de Oliveira Salvador, P. T. C., Dos Santos, J., Meira, K. C., Camacho, A. R., Guimarães, R. M., \& Souza, D. L. (2016). Trends and predictions for gastric cancer mortality in Brazil. World journal of gastroenterology, 22(28), 6527.

Viacava, F., \& Bellido, J. G. (2016). Health, access to services and sources of payment, according to household surveys. Ciência \& Saúde Coletiva, 21(2), 351-370.

Villaverde, R. M., Gordo, A. M. J., Del Moral, A. S. J., \& Álvarez-Mon Soto, M. (2017). Stomach cancer. Medicine;12:1904-10.

Vilela, R. P. B., Sanfelice, F. A. N., Alves, M. A., de Almeida, J. B., de Moura, K. R., Arruda, A. J., \& da Costa, A. M. (2018). Tendências de mortalidade por câncer segundo a Diretoria Regional de Saúde XV de São José do Rio Preto, São Paulo, Brasil. CuidArte Enfermagem, Catanduva, 12(2), 160-166.

Vigitel Brasil. (2016). Surveillance of risk factors and protection for chronic diseases by telephone survey: estimates of frequency and sociodemographic distribution of risk factors and protection for chronic diseases in the capitals of the 26 Brazilian states and in the Federal District in 2016 / Ministry of Health, Secretariat of Health Surveillance, Department of Surveillance of Diseases and Noncommunicable Diseases and Health Promotion - Brasília: Ministry of Health, 2017. https://bvsms.saude.gov.br/bvs/publicacoes/vigitel_brasil_2016_fatores_risco.pdf/

Toneto, M. G., \& Viola, L. (2018). Estado atual do tratamento multidisciplinar do adenocarcinoma gástrico. ABCD. Arquivos Brasileiros de Cirurgia Digestiva, 31 . 